ANALISIS PENGARUH DANA PIHAK KETIGA. NON PERFORMING FINANCE (NPF) DAN FINANCING TO DEPOSIT RATIO (FDR) TERHADAP PROFITABIUTAS PERBANKAN SYARIAH

DI INDONESIA YANI SURYANI

ANALISIS PENGARUH MERK DAGANG KUALITAS JASA DAN PROMOSI TERHADAP RETENSI PELANGGAN PADA USAHA WARUNG SELLULER DI KECAMATAN MEDAN DENAI SUNDAY ADE C OM SITORUS

INFLUENCE OF LEADERSHIP AND MOTIVATION OF THE WORK EMPLOYEE PERFORMANCE PT BANK SYARIAH MANDIRI, TBK MEDAN BRANCH PETISAH

RIZKY PUTRA

PENGARUH INFLASI DAN PERTUMBUHAN EKONOMI TERHADAP TINGKAT PENGANGGURAN DI SUMATERA UTARA (PERIODE 1990-2013) RAHIMA BR. PURBA

ANALISIS PENGARUH RETURN ON ASSETS (ROA), RETURN ON EQUITY (ROE) DAN CURRENT RATIO (CR) TERHADAP HARGA SAHAM PADA PERUSAHAAN MANUFAKTUR DI BURSA EFEK INDONESIA EVA MALINA SIMATUPANG

PENGARUH MOTIVASI BERWIRAUSAHA TERHADAP MINAT MAHASISWA MENJADI WIRAUSAHA (STUDI PADA MAHASISWA SEKOLAH TINGGI ILMU EKONOMI

IBBI MEDAN

LENNY MENARA SARI SARAGIH

PENGARUH KUALITAS PRODUK DAN PROMOSI TERHADAP KEPUTUSAN PEMBELIAN LAPTOP MEREK AS

PADA MAHASISWA FAKULTAS EKONO UNIVERSITAS SUMATERA UTARA

BUNGA ADIT! 


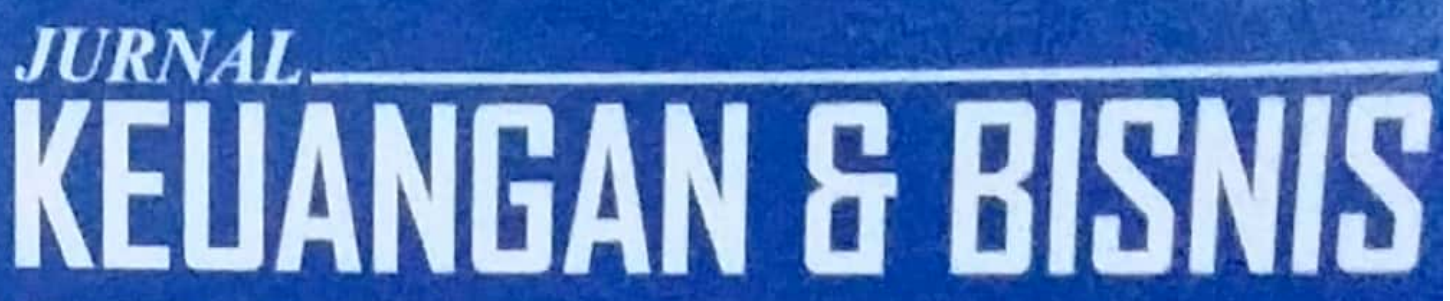

\section{PROGRAM STUDI MAGISTER MANAJEMEN SEKOLAH TINGGI ILMU EKONOMI HARAPAN}

ANALISIS PENGARUH DANA PIHAK KETIGA, NON PERFORMING FINANCE (NPF) DAN FINANCING TO DEPOSIT RATIO (FDR)

TERHADAP PROFITABILITAS PERBANKAN SYARIAH

DI INDONESIA

YANI SURYANI

ANALISIS PENGARUH MERK DAGANG, KUALITAS JASA DAN

PROMOSI TERHADAP RETENSI PELANGGAN PADA

USAHA WARUNG SELLULER DI KECAMATAN MEDAN DENAI

SUNDAY ADE C OM SITORUS

INFLUENCE OF LEADERSHIP AND MOTIVATION OF THE WORK EMPLOYEE PERFORMANCE PT BANK SYARIAH MANDIRI, TBK MEDAN BRANCH PETISAH

RIZKY PUTRA

PENGARUH INFLASI DAN PERTUMBUHAN EKONOMI TERHADAP TINGKAT PENGANGGURAN

DI SUMATERA UTARA (PERIODE 1990-2013)

RAHIMA BR. PURBA

ANALISIS PENGARUH RETURN ON ASSETS (ROA), RETURN ON EQUITY (ROE) DAN CURRENT RATIO (CR) TERHADAP HARGA SAHAM PADA PERUSAHAAN MANUFAKTUR DI BURSA EFEK INDONESIA

EVA MALINA SIMATUPANG

PENGARUH MOTIVASI BERWIRAUSAHA TERHADAP MINAT MAHASISWA MENJADI WIRAUSAHA (STUDI PADA MAHASISWA SEKOLAH TINGGI ILMU EKONOMI IBBI MEDAN)

\section{LENNY MENARA SARI SARAGIH}

PENGARUH KUALITAS PRODUK DAN PROMOSI TERHADAP KEPUTUSAN PEMBELIAN LAPTOP MEREK ASUS

PADA MAHASISWA FAKULTAS EKONOMI UNIVERSITAS SUMATERA UTARA

BUNGA ADITI 


\section{KATA PENGANTAR}

Dailan Junal Kéangan dan Busnia cdist ini, disajikan mjuh artikel penelifian Artikel. artikel penelitian yang dimaksud alalah artikel penclitiou di bidang ckonomi

Yani Suryani menulis aukel penclitan dengen judal Analisis Pongaroh Dama Pibak

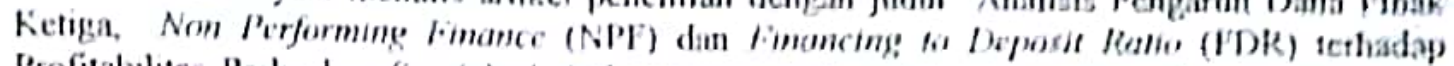
Profitabslitas Perbankan Syariah de Indenessa Penelition ini menarak mengingut perlufeugas kenntungan pada l'erbankan Syauah berbeda dengan perbankan konvensicnal

Artikel penclituan yang berjudul Analısis P'enganth Merek Digang. Kualitas Lasa dan Promosi terhadap Retensi Pelangean pada Isaha Warung Selleter di Kecamatau Medan Iscrai merupahan artikel penclitian yang ditulis olch Sunday Ade Artukel peneltitian ini netihat

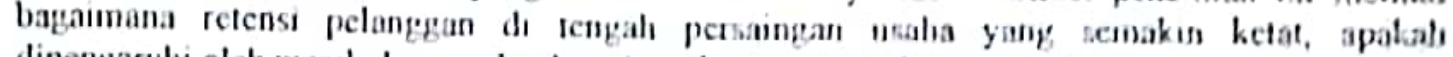
dipengarulii olch merek dagang. kualitas jasa dan promosi aban produk tersebut

Antikel penclitian yaung dotulas Ruzky Putra berjudul Influence of Lendership and Motwathom of The Work an limpleyee Performance at PT Bank Syariah Mandiri. The Medan Brameh Petisali Arlikel penelitan ini menyorot bazaunana pencisuli kepemimpman dan motivast kerja Icrhadap buncrja pegawai pada Bank Syanah Mandin Medan Cabang, Petisuh

Pengaruli Inflasi dan Pertumbulian Ehonomi terhadap Tmekat Pengangeuran di Simarera Utara (Periode 1990-2013) imerupakan judul antakel penelitan Kahuma Isi Purba.

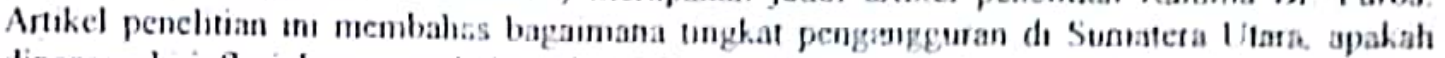
dipengaruh inflas! dan pertumbuhan ckonoms yang terjad pada tahun awatan

Analisis Pengauth Recurn (In Ase's (ROA), Return On Lqutty (ROL) dan (utremt katio (CR) Ierladap Ilarga Saham pada Perusahaan Munufaklum do Bursa Efeb Indotesa, diangkat Eva Malina Sumatupang menjad judul artikel penclıtian. Harga sahan pada purusulaan manufaktur yang berfluktuatir, inengingat jenis perusahaan mumufaktut yang banyak, dipengaruhi olch banyak faktor Pada penelitian ini, fuktor yarg diteliti adalah ROA. ROE dan CR

Artikel penelitian lannya merupakan artikel yang ditulis Lenny Menara San Soragh Artikel penchitan in berjudul Pengaruh Motrvasi Berwirausaha terhadap Minat Mahasiswa menjadi Wirausaha (Studi pada Mahasiswa Sckolah Tinggi llmu Ekonomi IBRI Medm). Berkembangny a kegratan wirausaha pada sat int, terutama di kalangan mahasiswa, menjadi isu yang menarik perhatian penuits untuk di teliti

Artikel penelitian terakhur dalam edisi ini merupakan artikel peselitian yang ditulis Bunga Aditi Artikel penclitian in berjudul Pengaruh Kualitas Produk dan Promosi terhadap Keputusan P'crnbelian Laptop Merek. Asus pada Mahasiswa Fakultas Ekonom Universitas Sumatera Ltara Keputusin pembelan suatu produk, dalam hal ini adalah laprop merek ASUS. dilıkat dari pengaruh kualıtas dan promosi dari produk itu sendıri.

Semoga artikel-arnkel penelitian dalum Jurnal Ketuangan dan Bisnis edisi ini bermanfaat bagi penbaca

Salam,

Editor 


\title{
PENGARUH KUALITAS PRODUK DAN PROMOSI TERHADAP KEPUTUSAN PEMBELIAN LAPTOP MEREK ASUS PADA MAHASISWA FAKULTAS EKONOMI SUMATERA UTARA
}

\author{
Bunga Aditi \\ Dosen fakultas ekonomi STIE Harapan Medan
}

\begin{abstract}
ABSTRAK
Pengambilan keputusan merupakan suatu kegiatan mahasiswa yang secara langsung terlibat dalam mendapatkan dan mempergunakan barang yang ditawarkan. Keputusan pembelian yang tinggi dari mahasiswa atas suatu produk merupakan aspek paling penting bagi suatu perusahaan dalam melakukan kegiatan bisnisnya. Untuk meningkatkan pembelian yang tinggi dari mahasiswa, perusahaan harus memperhatikan faktor-faktor yang mempengaruhi keputusan pembelian, diantaranya adalah kualitas produk dan adanya promosi. Tujuan dari penelitian ini adalah untuk pengaruh kualitas produk dan promosi terhadap keputusan pembelian mahasiswa pada Mahasiswa fakultas ekonomi Sumatera Utara. Jenis data yang digunakan adalah data sekunder. Teknik pengumpulan data dilakukan dengan teknik dokumentasi dan analisis data menggunakan analisis regresi linear berganda dengan Koefisien determinasi $\left(\mathrm{R}^{2}\right)$ Kualitas produk dan Promosi mampu menjelaskan variabel keputusan pembelian pada Mahasiswa fakultas ekonomi Sumatera Utara sebesar 72,1\%, sisanya sebesar 27,9\% dijelaskan oleh variabel-variabel independen yang tidak diteliti. Hasil penelitian menunjukkan bahwa Kualitas produk dan Promosi secara simultan berpengaruh positif dan signifikan terhadap keputusan pembelian laptop merek asus pada Mahasiswa fakultas ekonomi Sumatera Utara. Secara parsial masing-masing sama Kualitas produk dan Promosi berpengaruh positif dan signifikan terhadap keputusan pembelian laptop merek asus pada Mahasiswa fakultas ekonomi Sumatera Utara. Variabel promosi yang dominan dalam meningkatkan keputusan pembelian laptop merek asus pada Mahasiswa fakultas ekonomi Sumatera Utara.
\end{abstract}

Kata kunci : Kualitas produk, Promosi dan Keputusan Pembelian

\section{PENDAHULUAN}

Perkembangan laptop di Indonesia diawali sekitar tahun 1980-an dan digunakan untuk orang-orang tertentu saja. Perkembangan teknologi saat ini membawa pengaruh luar biasa bagi gaya hidup setiap orang, terutama dibidang teknologi informasi baik segi perangkat keras maupun perangkat lunak. Tidak dipungkiri lagi perkembangan komputer cukup mengesankan, dahulu komputer yang hanya digunakan untuk keperluan kantor, sekarang berkembang ke berbagai bidang seperti desain, game, dan hiburan. Pada awal-awal pertamanya komputer hanya dapat digunakan terbatas di meja saja atau yang sering disebut sebagai 1computer desktop (komputer duduk). Berkembangnya pola pikir dan peradaban manusia, muncul konsep atau ide bahwa komputer tidak hanya digunakan sebatas di atas meja saja, tetapi harus dapat digunakan untuk berpindah-pindah tempat (mobile). 
Dampak dari perkembangan Teknologi Informasi atau yang sering disebut dengan IT menjadi perhatian tersendiri bagi masyarakat, tidak menutup kemungkinan IT adalah suatu hal yang kini menjadi kebutuhan yang sangat penting bagi masyarakat dunia. Laptop nantinya akan mengalami perkembangan pasar yang menjanjikan bagi para pasar market IT. Laptop dalam beberapa tahun terakhir ini berkembang dengan sangat pesat dan pada awal tahun ini boleh dibilang melewati penjualan komputer desktop, dahulu laptop merupakan produk yang hanya digunakan oleh kalangan bisnis karena pada saat itu harga sebuah laptop dikatakan sangat mahal dan belum terjangkau oleh kalangan menengah. Tapi semakin banyak pabrikan yang memproduksi perangkat tersebut harga laptop jadi semakin terjangkau. Teknologi yang ditawarkan laptop semakin beragam, mulai dari prosesor yang ultra low voltage hingga yang menggunakan prosesor dan graphic card dengan kinerja tinggi yang digunakan para gamer.

Proses pengambilan keputusan pembelian laptop merek asus pada setiap orang pada dasarnya adalah sama, hanya saja semua proses tersebut tidak semua dilaksanakan oleh para mahasiswa. Perilaku mahasiswa dalam proses pengambilan keputusan untuk melakukan pembelian akan diwarnai oleh ciri kepribadiannya, usia, pendapatan dan gaya hidupnya. Saat ini banyak masyarakat memutuskan membeli laptop sebagai pilihan penggunaan alat elektronik pendukung teknologi informasi dibandingkan dengan PC (Personal Computer). Pada tahun 2005, jumlah laptop di Indonesia telah melampaui PC dalam jumlah yang signifikan sebagai sebuah fenomena yang mengisyaratkan adanya perubahan paradigma dalam perilaku mahasiswa menggunakan komputer.

Berbagai alasan yang melatar belakangi pilihan mahasiswa lebih memilih memutuskan membeli laptop daripada PC diantaranya adalah dapat dibawa dengan mudah kemana saja, lebih tipis, ringan, dapat digunakan kapan saja dan terlihat lebih mahal. Laptop selain dapat digunakan untuk melakukan pengolahan kegiatan administrasi perkantoran juga dapat digunakan untuk mengakses informasi dimana saja dan dalam waktu yang tidak terbatas.

Keputusan seorang membeli produk laptop dipengaruhi oleh beberapa faktor seperti : sikap mahasiswa yang terdiri dari evaluasi produk, respon, kepercayaan dan pengembangan produk (inovasi produk). Informasi mengenai produk mendasari proses membeli sehingga akhirnya muncul suatu kebutuhan, di sini mahasiswa akan mempertimbangkan dan memahami kebutuhan tersebut, apabila penilaian pada produk sudah jelas maka mahasiswa akan mencari produk yang dimaksud, yang kemudian akan berlanjut pada evaluasi produk dan akhirnya mahasiswa akan mengambil keputusan untuk membeli atau memutuskan untuk tidak membeli yang disebabkan produk tidak sesuai dan mempertimbangkan atau menunda pembelian pada masa yang akan datang.

Pengembangan produk laptop merek Asus bergerak sesuai dengan perkembangan dan teknologi dengan mengkonversikan penerapan untuk mengahasilkan produk yang dapat dipasarkan. Portability adalah kunci paling kuat yang membuat laptop merek Asus mampu bertahan hingga sekarang 
disamping performa yang maksimal mendekati desktop PC. Namun saat ini kunci kesuksesan laptop merek Asus terlihat bercabang, dan tidak hanya mengandalkan portabilitas ataupun ukuran saja, faktor powerful, stylish seakan wajib untuk menjadikan sebuah laptop merek Asus diminati banyak mahasiswa. Beranjak beberapa tahun kedepan laptop merek Asus telah dibekali dengan Wireless connectivity baik Bluetooth ataupun Wi-Fi, DVD drives, advanced graphics cards, layar wide-screens ataupun layar "pocketables", yang membuat mahasiswa ingin memilikinya, dan faktor yang lain seperti arah gerak laptop merek Asus yang desainnya semakin kecil, manis, dan keren dibanding sebelumnya.

Pemahaman kebutuhan dan proses pembelian mahasiswa adalah sangat penting dalam membangun strategi pemasaran yang efektif. Dengan mengerti bagaimana pembeli melalui proses pengenalan masalah hingga ke perilaku setelah pembelian, para pemasar dapat mengerti isyarat-isyarat penting bagimana memenuhi kebutuhan pembeli. Selain itu dengan mengerti berbagai partisipan dalam proses pembelian dan pengaruh-pengaruh utama dalam perilaku membeli mereka. Secara sadar maupun tidak, tindakan mahasiswa dipengaruhi oleh sikap. Kenyataan yang ada telah membuktikan bahwasannya sikap mahasiswa turut mempengaruhi keputusan pembelian laptop merek asus. Hasil penelitian yang dilakukan oleh para ahli menunjukkan bahwa terdapat pengaruh yang signifikan antara sikap terhadap keputusan pembelian laptop merek asus yang dilakukan oleh mahasiswa. Berkaitan dengan perubahan sikap mahasiswa dalam memilih produk laptop merek Asus juga dipicu dangan banyaknya kemunculan baru yang turut meramaikan persaingan laptop di pasar elektronik.

Sikap mahasiswa dapat dikatakan sesuatu yang unik, karena preferensi dan sikap terhadap produk setiap orang berbeda. Selain itu mahasiswa berasal dari beberapa segmen, sehingga apa yang diinginkan dan dibutuhkan juga berbeda dan sikap mahasiswa terhadap suatu merek produk akan bervariasi tingkatannya, ada yang sangat menyukai atau bahkan ada yang begitu sangat tidak menyukainya. Ketika mahasiswa menyatakan derajat tingkat kesukaan terhadap suatu produk, maka ia mengungkapkan intensitas sikapnya. Produsen perlu memahami sikap mahasiswa terhadap produk atau merek yang ada di pasar, selanjutnya perlu dilakukan berbagai cara untuk membuat mahasiswa tertarik terhadap produk yang dihasilkan.

\section{LANDASAN TEORITIS Kualitas Produk}

Menurut Kotler dan Amstrong (2008:272) "Kualitas produk (product quality) adalah salah satu sarana positioning untuk pemasar. Kualitas produk adalah karakteristik produk atau jasa yang tergantung pada kemampuanya untuk memuaskan kebutuhan pelanggan yang dinyatakan atau diimplikasikan. Kualitas Produk juga didefinisikan sebagai "bebas dari kerusakan".

Menurut Siemens dalam Kotler dan Armstrong (2008:273) juga mendefinisikan kualitas dengan cara ini: "Kualitas adalah ketika pelanggan kita kembali dan produk kita tidak kembali". Kotler dan Amstrong dalam Putri (2010:15) "Kualitas produk adalah mencerminkan kemampuan produk untuk menjalankan tugasnya yang mencakup daya tahan, kehandalan atau kemajuan, kekuatan, kemudahan dalam pengemasan dan reparasi produk dan ciri-ciri lainnya". 


\section{Promosi}

Menurut Hasan (2013:603) "Promosi merupakan proses mengkomunikasikan variabel bauran pemasaran (marketing mix) yang sangat penting untuk dilaksanakan oleh perusahaan dalam memasarkan produk. Inti dari kegiatan promosi adalah suatu bentuk kegiatan komunikasi pemasaran yang berusaha untuk menyebarkan informasi perusahaan, memengaruhi, mengingatkan pasar sasaran agar bersedia menerima, membeli dan loyal pada produk yang ditawarkan oleh perusahaan (penjual dan pembeli)".

Menurut Hamdani dalam Sunyoto (2013:154) "Promosi merupakan salah satu variabel dalam bauran pemasaran yang sangat penting dilaksanakan dalam memasarkan produk. Kegiatan promosi bukan saja berfungsi sebagai alat komunikasi antara perusahaan dengan konsumen, melainkan juga sebagai alat untuk memengaruhi konsumen dalam kegiatan pembelian atau penggunaan produk sesuai dengan kebutuhan dan keinginannya".

Menurut Gitosudarmon dalam Sunyoto (2013:155) "Promosi adalah merupakan kegiatan yang ditujukan untuk mempengaruhi konsumen agar mereka dapat menjadi kenal akan produk yang ditawarkan oleh perusahaan kepada mereka dan kemudian mereka menjadi senang lalu membeli produk tersebut. Adapun alat-alat yang dapat dipergunakan untuk mempromosikan suatu produk dapat dipilih beberapa cara, yaitu iklan, promosi penjualan, publisitas, personal selling yang disebut sebagai bauran promosi".

\section{Keputusan Pembelian Konsumen}

Setiadi dalam Sopiah dan Mamang (2013:121) mendefenisikan bahwa inti dari "Keputusan pembelian konsumen adalah proses pengintegrasian yang mengkombinasikan pengetahuan untuk mengevaluasi dua perilaku alternatif atau lebih, dan memilih salah satu diantaranya. Hasil dari proses pengintegrasian ini adalah suatu pilihan yang disajikan secara kognitif sebagai keinginan berperilaku".

Menurut Peter dan Olson dalam Sopiah dan Mamang (2013:163-164) inti dalam "Pengambilan keputusan konsumen (consumer decision making) adalah proses integrasi yang digunakan untuk mengkombinasikan pengetahuan untuk mengevaluasi dua atau atau lebih perilaku alternatif dan memilih satu diantaranya. Hasil proses integrasi tersebut adalah suatu pilihan (choice), secara kognitif menunjukkan intensi perilaku (suatu rencana keputusan)".

Schiffman dan kanuk dalam Sopiah dan Mamang (2013:120) "Mendefinisikan keputusan sebagai pemilihan suatu tindakan dari dua pilihan alternatif atau lebih. Seorang konsumen yang hendak memilih harus memiliki pilihan alternatif. Suatu keputusan tanpa pilihan disebut "pilihan Hobson".

\section{Kerangka Konseptual}

Menurut Hasan (2014:178-179) "Dilihat dari sudut perilaku konsumen misalnya saja persepsi dan sikap terhadap kualitas produk dan kesesuaiannya terhadap diri dan keluarga mereka, memilih dampak yang sangat besar terhadap cara mereka menilai dan mengambil keputusan untuk melakukan pembelian termasuk dalam melakukan pembelian ulang". 
Menurut kotler dan Keller (2009:9) "Pembeli mengharapkan produk mempunyai kualitas kesesuaian (conformance quality) yang tinggi, yaitu tingkat dimana semua unit yang diproduksi identik dan memenuhi spesifikasi yang dijanjikan".

Kualitas produk erat kaitannya dengan keputusan pembelian, di mana kualitas produk menjadi salah satu aspek pertimbangan konsumen dalam memutuskan pembelian. Kualitas yang baik akan berujung pada kepuasan konsumen yang selanjutnya akan membuat konsumen tersebut menjadi loyal terhadap produk tersebut. Perusahaan harus dapat memberikan kualitas yang sesuai dengan keinginan dan kebutuhan konsumen dengan memperhatikan standar-standar kualitas pasar yang ada. Hal ini dimaksudkan agar kualitas yang diberikan perusahaan tersebut tidak kalah saing dibandingkan perusahaan kompetitornya (Jurnal Selestio, 2013:43).

Kualitas produk terhadap keputusan pembelian sangat erat kaitannya. Konsumen pasti ingin mendapatkan produk yang sesuai dengan kebutuhan dan keinginan mereka. Produk yang berkualitas yaitu produk yang sesuai dengan kebutuhan dan keinginan konsumen sehingga akan mendorong konsumen untuk melakukan pembelian produk tersebut. Kualitas dari sebuah produk merupakan salah satu pertimbangan penting konsumen dalam pengambilan keputusan pembelian. Memberikan kualitas produk yang tinggi merupakan kewajiban perusahaan untuk mengapai tujuannya. Kualitas produk yang baik membuat konsumen cenderung melakukan keputusan pembelian, namun jika kualitas produk tersebut jelek maka kemungkinan konsumen tidak akan melakukan keputusan pembelian produk tersebut. Penjualan produk dengan kualitas yang bagus, orisinil, resmi akan meningkatkan kepercayaan konsumen dalam hal keandalan produk.

Menurut Mulyadi (2013:202) "Implikasi promosi akan mempengaruhi perilaku konsumen dalam melakukan keputusan pembelian dimana konsumen akan senantiasa merasa diingatkan kepada merek produk yang dipasarkan minat beli perusahaan". Menurut Hasan (2013:173). Menurut Rangkuti (2009:28-29) "Promosi penjualan adalah salah satu kegiatan promosi untuk melakukan rangsangan kepada konsumen untuk melakukan pembelian. Jadi promosi penjualan merupakan kegiatan promosi yang dapat mendorong pembelian oleh konsumen, dan yang dapat meningkatkan efektivitas para distributor atau retailer dengan mengadakan pameran, display, eksibisi, peragaan, dan berbagai kegiatan penjualan lainnya, yang dilakukan sewaktu-waktu dan bersifat tidak rutin".

Promosi merupakan kegiatan terpenting yang berperan aktif dalam memperkenalkan, memberitahukan, dan mengingat kembali manfaat suatu produk yang dapat mendorong konsumen untuk membeli produk yang dipromosikan tersebut. Dalam mengadakan promosi perusahaan diharuskan menentukan dengan tepat alat promosi mana yang akan digunakan agar dapat tercapainya keberhasilan dalam tujuan promosi itu (Jurnal Selestio, 2013:51). Dari beberapa uraian-uraian teori di atas tentang kualitas produk dan romosi terhadap keputusan pembelian konsumen maka dapat dibuat kerangka konseptual sebagai berikut :

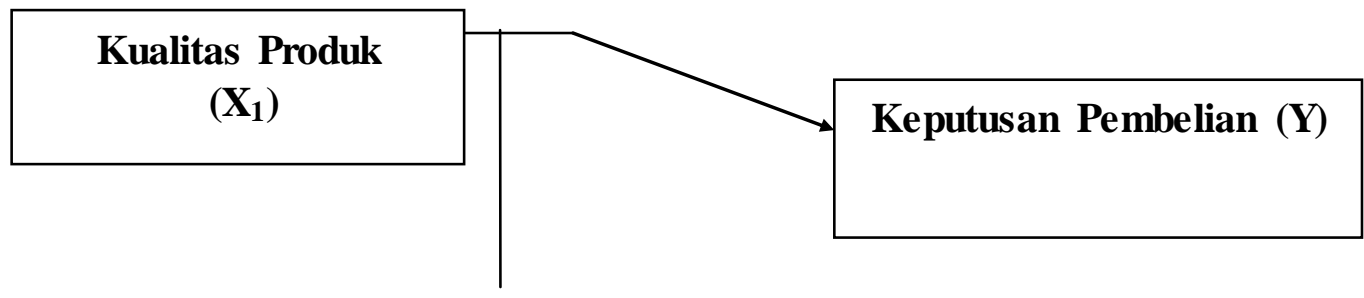




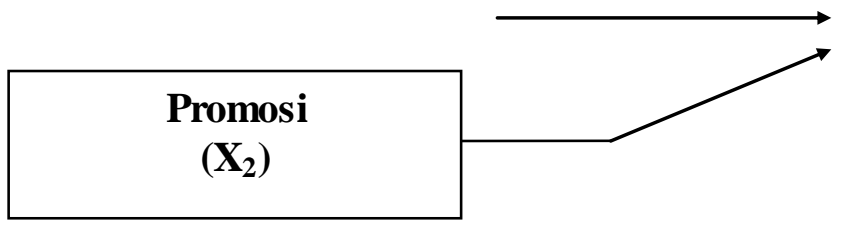

Gambar 1 Kerangka Konseptual

\section{Hipotes is Penelitian}

1. Kualitas produk berpengaruh positif dan signifikan terhadap keputusan pembelian konsumen pada Mahasiswa fakultas ekonomi Sumatera Utara.

2. Promosi berpengaruh positif dan signifikan terhadap keputusan pembelian konsumen pada Mahasiswa fakultas ekonomi Sumatera Utara.

3. Kualitas produk dan promosi berpengaruh positif dan signifikan terhadap keputusan pembelian konsumen pada Mahasiswa fakultas ekonomi Sumatera Utara.

\section{METODE PENELITIAN}

\section{Jenis dan Lokasi Penelitian}

Jenis penelitian ini berupa deskriptif kuantitatif yaitu penelitian yang mengukur kekuatan hubungan antara dua variabel atau lebih. Pendekatan yang digunakan dalam penelitian ini adalah pendekatan survei yaitu kegiatan mengumpulkan data sebanyak-banyaknya mengenai fakta-fakta yang merupakan pendukung terhadap penelitian dengan maksud untuk mengetahui status, gejala menemukan kesamaan status dengan cara membandingkan dengan standar yang sudah dipilih atau ditentukan (Arikunto, 2010). Adapun sifat penelitian ini adalah explanatory research yaitu bertujuan untuk menjelaskan kedudukan variabelvariabel yang diteliti serta hubungan antara variabel yang lain (Sugiyono, 2010).

\section{Pengambilan Sampel}

Populasi adalah gabungan dari seluruh elemen yang berbentuk peristiwa, hal, atau orang yang memiliki karakteristik yang serupa yang menjadi pusat semesta penelitian (Ferdinand, 2006). Dalam penelitian ini populasi yang dimaksud adalah seluruh mahasiswa fakultas ekonomi. Sampel sebanyak 92 responden dengan menggunakan rumus slovin.

\section{Definisi Ope rasional Variabel}

Variabel - variabel penelitian tersebut dapat didefinisikan dan diukur sebagai berikut :

Kualitas produk $\left(\mathrm{X}_{1}\right)$ adalah salah satu sarana positioning untuk pemasar. Kualitas produk adalah karakteristik produk atau jasa yang tergantung pada kemampuanya untuk memuaskan kebutuhan pelanggan yang dinyatakan atau diimplikasikan.

Promosi $\left(\mathrm{X}_{2}\right)$ adalah merupakan kegiatan yang ditujukan untuk mempengaruhi konsumen agar mereka dapat menjadi kenal akan produk yang ditawarkan oleh perusahaan kepada mereka dan kemudian mereka menjadi senang lalu membeli produk tersebut. Menurut Gitosudarmon dalam Sunyoto (2013:155)

Keputusan pembelian (Y) adalah proses pemecahan masalah yang diarahkan pada sasaran. Menurut Peter dan Olson dalam Sopiah dan Mamang (2013:332) 


\section{Metode Analis is Data}

Adapun model yang digunakan dalam perhitungan analisis regresi linier berganda adalah sebagai berikut :

$$
\mathrm{Y}=\mathrm{a}+\mathrm{b}_{1} \mathrm{X}_{1}+\mathrm{b}_{2} \mathrm{X}_{2}+\mathrm{e}
$$

Dimana :

$\mathrm{Y} \quad=$ Keputusan pembelian

$\mathrm{a} \quad=$ Konstanta

$\mathrm{b}_{1} \quad=$ Koefisien regresi variabel $\mathrm{X}_{1}$

$\mathrm{b}_{2}=$ Koefisien regresi variabel $\mathrm{X}_{2}$

$\mathrm{X}_{1}=$ Kualitas produk

$\mathrm{X}_{2}=$ Promosi

$\mathrm{e} \quad=$ error

Pengujian Hipotesis dalam penelitian ini adalah sebagai berikut :

a. Uji Determinasi $\left(\mathrm{R}^{2}\right)$

Uji ini dilakukan untuk mengetahui seberapa besar persentase variabel bebas mampu menerangkan variabel terikat. Uji ini dapat dilihat dengan menggunakan rumus determinan

b. Uji secara Simultan/Serempak (Uji-F)

Pengujian ini dilakukan untuk melihat apakah semua variabel bebas yang dimasukkan dalam model mempunyai pengaruh secara simultan (serempak) terhadap variabel terikat.

Pengaruh variabel independen terhadap dependen di uji dengan tingkat kepercayaan (confidence interval) 95\% atau pada alpha $\alpha=5 \%$. Untuk menguji apakah hipotesis ditolak atau diterima digunakan statistik uji $\mathrm{F}$ :

Jika $\mathrm{F}_{\text {hitung }}<\mathrm{F}_{\text {tabel }}$, maka $\mathrm{H}_{0}$ diterima dan $\mathrm{H}_{\mathrm{a}}$ ditolak, dan

Jika $\mathrm{F}_{\text {hitung }}>\mathrm{F}_{\text {tabel }}$, maka $\mathrm{H}_{0}$ ditolak dan $\mathrm{H}_{\mathrm{a}}$ diterima.

b. Uji secara Parsial/Individual (Uji-t)

Uji parsial dilakukan untuk mengetahui pengaruh masing-masing variabel bebas terhadap variabel terikat. Kriteria pengujian dilakukan dengan membandingkan nilai t-hitung dengan $\mathrm{t}$-tabel yaitu :

a) Jika t-hitung > t-tabel, tolak $\mathrm{H}_{\mathrm{o}}$ terima $\mathrm{H}_{\mathrm{a}}$ pada taraf signifikan $95 \%$

b) Jika t-hitung < t-tabel, terima $\mathrm{H}_{\mathrm{o}}$ tolak $\mathrm{H}_{\mathrm{a}}$ pada taraf signifikan $95 \%$

\section{HASIL DAN PEMBAHASAN}

\section{Pengujian Asumsi Klasik}

Pengujian asumsi klasik digunakan untuk mengetahui model regresi linear berganda dapat digunakan atau tidak. Apabila uji ini terpenuhi maka alat uji dimaksud dapat dipergunakan untuk menguji model yang terdiri dari :

\section{Uji Normalitas}

Pada diagram pencar hasil olah data SPSS dengan dasar pengambilan keputusan yakni jika data menyebar disekitar garis diagonal dan mengikuti arah garis diagonal, maka model regresi memenuhi asumsi normalitas. Hasil pengujian normalitas dapat dilihat pada Gambar 2: 


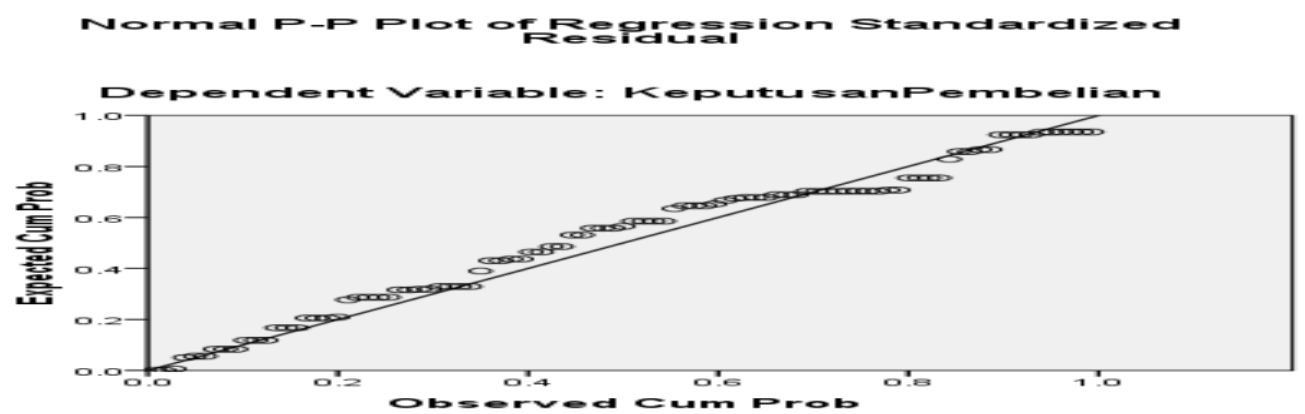

Sumber: Hasil Penelitian, 2015 (data diolah)

Gambar 2 Diagram Pencar Hasil SPSS

Pada Gambar 2 dapat dilihat data menyebar disekitar garis diagonal dan menunjukkan bahwa data berdistribusi normal.

\section{Uji Multikolonieritas}

Berdasarkan hasil pengolahan SPSS dilihat pada Tabel 1:

Tabel 2 Hasil Uji Multikolinieritas

\begin{tabular}{|c|c|c|c|}
\hline \multirow{2}{*}{\multicolumn{2}{|c|}{ Model }} & \multicolumn{2}{|c|}{ Collinearity Statistics } \\
\hline & & Tolerance & VIF \\
\hline \multirow[t]{2}{*}{1} & KualitasProduk & .461 & 2.170 \\
\hline & Promosi & .461 & 2.170 \\
\hline
\end{tabular}

Sumber: Hasil Penelitian, 2015 (data diolah)

Pada Tabel 1 hasil variabel Kualitas produk dan Promosi nilai VIF lebih kecil dari 10 dan niai tolerance mendekati 1 . Hal ini menunjukkan tidak terjadi gejala multikolonieritas.

\section{Uji Heteroskedastisitas}

Uji Heteroskedastisitas bertujuan untuk mengetahui dalam sebuah regressi terjadi kesamaan varians residual, jika varians pengamatan tetap maka disebut homokedasitas, dan jika berbeda disebut heteroskedastisitas, dan model yang baik tentunya tidak terjadi heteroskedastisitas. Dari hasil pengolahan dengan menggunakan SPSS hasil pengolahan data penelitian untuk scatter plot dengan Regression Studentized Residual dapat dilihat pada gambar 2:

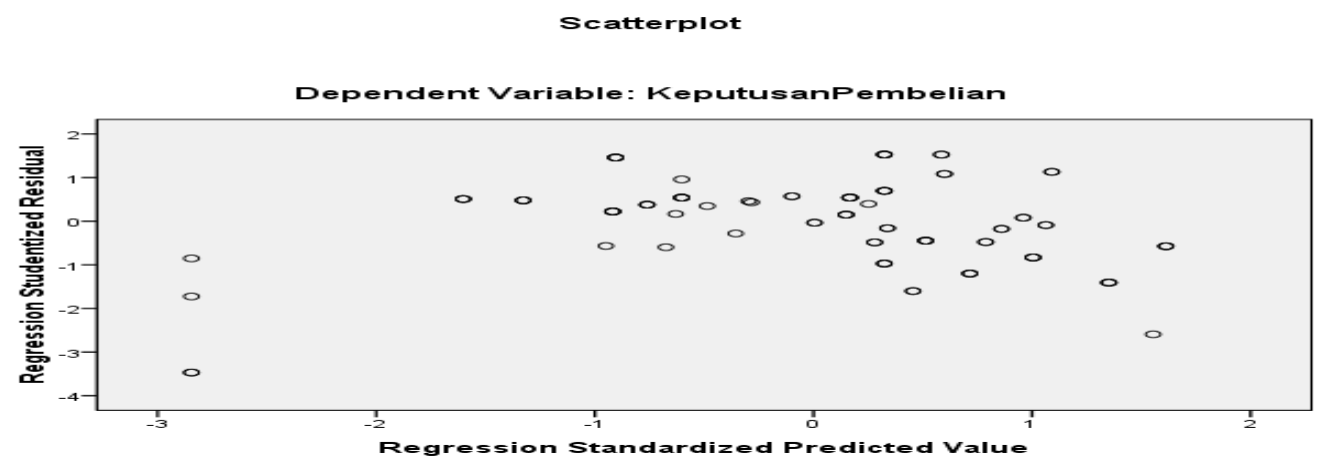

Sumber: Hasil Penelitian, 2015 (data diolah)

Gambar 2 Uji Heteroskedastisitas 
Pada Gambar 2 terlihat titik yang menyebar yang tidak membentuk polapola tertentu dan tersebar baik diatas angka 0 pada sumbu Regression Studentized Residual (y) dan berdasarkan gambar tersebut maka tidak terjadi heteroskedastisitas sehingga model regressi layak dipakai untuk memprediksi Keputusan pembelian laptop merek asus pada mahasiswa berdasarkan variabel independen.

\section{Pengujian Hipotesis}

Analisis Persamaan Regresi Linear Berganda

Berdasarkan hasil Persamaan Regresi Linear Berganda diperoleh hasil seperti Tabel 3:

Tabel 3 Hasil Uji Regresi Linier Berganda

\begin{tabular}{|ll|r|r|r|r|r|}
\hline \multirow{2}{*}{ Model } & \multicolumn{2}{|c|}{$\begin{array}{c}\text { Unstandardized } \\
\text { Coefficients }\end{array}$} & \multicolumn{2}{c|}{$\begin{array}{c}\text { Standardized } \\
\text { Coefficients }\end{array}$} & \multicolumn{2}{|c|}{} \\
\cline { 2 - 7 } & \multicolumn{1}{|c|}{ B } & Std. Error & Beta & \multicolumn{1}{c|}{ t } & \multicolumn{1}{c|}{ Sig. } \\
\hline $1 \quad$ (Constant) & 8.689 & 1.987 & & 4.373 & .000 \\
& KualitasProduk & .281 & .069 & .329 & 4.057 & .000 \\
& Promosi & .510 & .071 & .582 & 7.177 & .000 \\
\hline
\end{tabular}

Sumber: Hasil Penelitian, 2015 (data diolah)

Berdasarkan Tabel 3 maka persamaan regresi linier berganda dalam penelitian ini sebagai berikut:

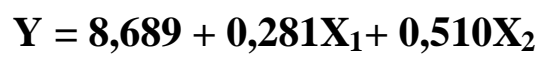

1. Nilai konstanta regresi sebesar 8,689 artinya jika Kualitas produk $\left(\mathrm{X}_{1}\right)$ dan Promosi $\left(\mathrm{X}_{2}\right)=0$ maka Keputusan pembelian laptop merek asus pada mahasiswa akan meningkat sebesar 8,689.

2. Koefisien regresi $X_{1}$ untuk variabel Kualitas produk bernilai positif 0,281 artinya bahwa pengaruh variabel Kualitas produk searah dengan peningkatan keputusan pembelian laptop merek asus pada mahasiswa. Hal ini menunjukkan bahwa variabel Kualitas produk mempunyai pengaruh positif dalam meningkatkan keputusan pembelian laptop merek asus pada mahasiswa.

3. Koefisien regresi $X_{2}$ untuk variabel Promosi bernilai positif 0,510 artinya artinya bahwa pengaruh variabel promosi searah dengan peningkatan keputusan pembelian laptop merek asus mahasiswa. Hal ini menunjukkan bahwa variabel promosi mempunyai pengaruh positif dalam meningkatkan keputusan pembelian laptop merek asus pada mahasiswa.

Pada Tabel 3 Hasil uji parsial diperoleh hasil sebagai berikut:

1. Nilai $t$ hitung untuk variabel Kualitas produk (4.057) lebih besar dibandingkan dengan nilai $\mathrm{t}$ tabel $(1,66)$, atau nilai sig $\mathrm{t}$ untuk variabel Kualitas produk $(0,000)$ lebih kecil dari alpha $(0,05)$. Berdasarkan hasil yang diperoleh maka menolak $\mathrm{Ho}$ dan menerima $\mathrm{H}_{1}$ untuk variabel Kualitas produk. Dengan demikian, secara parsial Kualitas produk berpengaruh positif dan signifikan terhadap keputusan pembelian laptop merek asus pada mahasiswa. Hal ini memberi arti bahwa Kualitas produk berpengaruh nyata dalam meningkatkan keputusan pembelian laptop merek asus pada mahasiswa. 
2. Nilai t hitung untuk variabel Promosi $(7,177)$ lebih besar dibandingkan dengan nilai $\mathrm{t}$ tabel $(1,66)$, atau nilai sig $\mathrm{t}$ untuk variabel Promosi $(0,000)$ lebih kecil dari alpha $(0,05)$. Berdasarkan hasil yang diperoleh maka menolak H0 dan menerima H1 untuk variabel Promosi. Dengan demikian, secara parsial Promosi berpengaruh positif dan signifikan terhadap keputusan pembelian laptop merek asus pada mahasiswa. Hal ini memberi arti bahwa dengan adanya Promosi memberikan dampak pada peningkatan keputusan pembelian laptop merek asus pada mahasiswa. Secara parsial variabel promosi yang dominan mempengaruhi keputusan pembelian laptop merek asus pada mahasiswa, Maksudnya adalah, variabel promosi lebih menentukan dalam meningkatkan keputusan pembelian laptop merek asus pada mahasiswa dibandingkan dengan kualitas produk.

\section{Koefisien Determinasi $\left(\mathbf{R}^{2}\right)$}

Koefisien determinasi merupakan besaran yang menunjukkan besarnya variasi variabel dependen (Keputusan pembelian) yang dapat dijelaskan oleh variabel independen (Kualitas produk dan Promosi). Nilai koefisien determinasi ditentukan dengan nilai $R$ square, dapat dilihat pada Tabel 4:

Tabel 4 Nilai Koefisien Determinasi (R Square)

\begin{tabular}{|c|c|c|c|c|}
\hline \multirow{2}{*}{ Model } & \multicolumn{4}{|c|}{} \\
\cline { 2 - 5 } & $\mathrm{R}$ & R Square & Adjusted R Square & Std. Error of the Estimate \\
\hline 1 & $.853^{\mathrm{a}}$ & .727 & .721 & 2.41610 \\
\hline
\end{tabular}

Sumber: Hasil Penelitian, 2015 (data diolah)

Berdasarkan Tabel 4 nilai adjusted $R$ Square adalah 0,721, artinya bahwa kemampuan variabel Kualitas produk $\left(\mathrm{X}_{1}\right)$ dan Promosi $\left(\mathrm{X}_{2}\right)$ dapat menjelaskan variasi dari keputusan pembelian laptop merek asus adalah sebesar $72,1 \%$, sisanya sebesar 27,9\% dijelaskan oleh variabel-variabel independen yang tidak diteliti seperti harga dan lokasi.

\section{Uji Simultan / Uji F}

Uji simultan / uji F dilakukan untuk mengetahui tingkat positif dan signifikansi dari variabel Kualitas produk dan Promosi terhadap variabel keputusan pembelian laptop merek asus pada mahasiswa dapat dilihat pada Tabel 5:

Tabel 5 Hasil Pengujian Hipotesis Secara Simultan / Uji F

\begin{tabular}{|ll|r|r|r|r|r|}
\hline Model & Sum of Squares & df & Mean Square & F & Sig. \\
\hline $1 \quad$ Regression & 1402.233 & 2 & 701.116 & 120.104 & $.000^{\mathrm{a}}$ \\
& Residual & 525.380 & 90 & 5.838 & & \\
\multicolumn{1}{|c|}{ Total } & 1927.613 & 92 & & & \\
\hline
\end{tabular}

Sumber: Hasil Penelitian, 2015 (data diolah)

Pada Tabel 5 diperoleh hasil $\mathrm{F}_{\text {Hitung }} 120.104$ sedangkan $\mathrm{F}$ Tabel pada $\alpha=$ 0,05 dengan derajat pembilang 2 dan derajat penyebut 90 diperoleh $\mathrm{F}$ tabel 2,35 dari hasil ini diketahui $\mathrm{F}$ hitung $>\mathrm{F}_{\text {tabel, }}$ dan signifikansi 0,000 atau lebih kecil dari $\alpha=0,05$ jadi posisi titik uji signifikansi berada pada wilayah penolakan $\mathrm{H}_{0}$ atau 
dapat disimpulkan $\mathrm{H}_{1}$ diterima yang artinya bahwa variabel Kualitas produk dan Promosi secara bersama-sama berpengaruh positif dan signifikan terhadap variabel Keputusan pembelian laptop merek asus pada mahasiswa.

\section{Pembahasan}

Pengaruh Kualitas produk dan Promosi terhadap Keputusan pembelian laptop merek asus pada Mahasiswa

Hasil penelitian yang telah dilakukan secara bersama sama Kualitas produk dan Promosi berpengaruh prositif dan signifikan terhadap keputusan pembelian mahasiswa pada Mahasiswa fakultas ekonomi Sumatera Utara. Hal ini menunjukkan bahwa Kualitas produk dan promosi berpengaruh nyata dalam meningkatkan keputusan pembelian mahasiswa.

Hasil penelitian diperoleh bahwa variabel kualitas produk berpengaruh positif dan signifikan terhadap keputusan pembelian mahasiswa pada Mahasiswa fakultas ekonomi Sumatera Utara. Kualitas produk menunjuk salah satu sarana positioning untuk pemasar. Kualitas produk adalah karakteristik produk atau jasa yang tergantung pada kemampuanya untuk memuaskan kebutuhan pelanggan yang dinyatakan atau diimplikasikan. Hal tersebut dibuktikan dengan hasil analisis uji t yang menunjukkan adanya pengaruh positif dan signifikan Kualitas produk terhadap keputusan pembelian mahasiswa.

Hasil penelitian diperoleh bahwa variabel promosi berpengaruh positif dan signifikan terhadap keputusan pembelian Mahasiswa fakultas ekonomi Sumatera Utara. Promosi sebagai kegiatan yang ditujukan untuk mempengaruhi mahasiswa agar mereka dapat menjadi kenal akan produk yang ditawarkan oleh perusahaan kepada mereka dan kemudian mereka menjadi senang.

\section{KESIMPULAN}

Berdasarkan pengujian yang telah dilakukan, maka dapat diperoleh kesimpulan sebagai berikut:

1. Berdasarkan hasil uji statistika secara simultan kualitas produk dan promosi berpengaruh positif dan signifikan terhadap Keputusan pembelian laptop merek asus pada mahasiswa.

2. Berdasarkan hasil uji statistika secara parsial kualitas produk berpengaruh positif dan signifikan terhadap Keputusan pembelian laptop merek asus pada mahasiswa.

3. Berdasarkan hasil uji statistika secara parsial promosi berpengaruh positif dan signifikan terhadap variabel Keputusan pembelian laptop merek asus pada mahasiswa.

\section{DAFTAR PUSTAKA}

Arikunto, Suharsimi. 2007. Manajemen Penelitian. Rineka Cipta. Jakarta.

Assauri, Sofjan, 2007. Manajemen Pemasaran. Rajawali Pers. Jakarta.

Fajar, Laksana. 2008. Manajemen Pemasaran. Graha Ilmu. Yogyakarta.

Ghozali, Imam, 2005. Apilkasi Analisis Multivariate Dengan Program SPSS. Badan Penerbit Universitas Diponegoro. Semarang.

Hasan, Ali. 2013. Marketing dan Kasus-Kasus Pilihan. Yogyakarta:CAPS (Center for Academic Publishing Service). 
Kotler, Philip dan Kevin Lane Keller, 2008. Manajemen Pemasaran. Jilid Satu, Edisi Keduabelas. Cetakan Ketiga. Penerbit Indeks.

Nitisusastro, Mulyadi, 2013. Perilaku Konsumen Dalam Perspektif Kewirausahaan. Alfabeta, Bandung.

Putri, Ika Iswayanti, 2010. Analisis pengaruh Kualitas produk, kualitas layanan, Harga, dan tempat terhadap keputusan pembelian (Studi pada rumah makan "Soto Angkring Mas Boed" di Semarang). Skripsi. Fakultas ekonomi. Universitas diponegoro. Semarang.

Sanusi, Anwar 2011. Metode Penelitian Bisnis, Salemba Empat. Jakarta.

Sugiyono. 2012. Metode Penelitian Bisnis. Cetakan Keenam Belas, CV Alfabeta. Bandung. 